\title{
ANTIBACTERIAL AND ANTIOXIDANT ACTIVITIES OF STEM BARK ESSENTIAL OIL CONSTITUENTS OF LITSEA GLUTINOSA C. B. ROB.
}

\author{
ARUNODAYA H. S., KRISHNA V.*, SHASHIKUMAR R., GIRISH KUMAR K.
}

Department of PG Studies and Research in Biotechnology and Bioinformatics, Kuvempu University, Shankaraghatta 577451, Karnataka, India Email: krishnabiotech2003@gmail.com

Received: 20 Jun 2016 Revised and Accepted: 21 Oct 2016

ABSTRACT

Objective: To evaluate the chemical composition, antibacterial and antioxidant properties of stem bark essential oil of Litsea glutinosa C. B. Rob.

Methods: The essential oil isolated from stem bark of L. glutinosa and their chemical composition was analyzed by gas chromatography coupled with mass spectrometry detector. The in vitro antibacterial activity of the stem bark essential oil was investigated against eight human pathogenic bacterial clinical isolates using agar disc diffusion method and MIC value was determined by modified resazurin microtitre-plate assay. The antioxidant activity of essential oil was measured by 2, 2-diphenyl-1-picrylhydrazyl radical (DPPH), 2, 2-azinobis-3-ethylbenzothiazoline-6sulphonate radical cation (ABTS) and $\beta$-carotene bleaching assay.

Results: GC-MS analysis of stem bark essential oil resulted in the identification of 37 compounds, off which 9,12-octadecadienoic acid (62.57\%), hexadecanoic acid (12.68\%), stigmast-5-en-3-ol (6.87\%) and vitamin E $(2.51 \%)$ were the main constituents representing $84.63 \%$ of the oil. The determination of in vitro antibacterial activity of stem bark essential oil resulted in significant inhibition zone (15.00 \pm 0.57 mm) and MIC value $\left(0.15 \pm 0.15 \times 10^{-2} \mathrm{mg} / \mathrm{ml}\right)$ against the pathogenic bacteria Vibrio cholera followed by Pseudomonas aeruginosa and Salmonella typhi. The results of DPPH radical scavenging (IC $50: 4.540 \pm 0.06 \mu \mathrm{g} / \mathrm{ml}$ ), ABTS $\left(\mathrm{IC}_{50}: 256.02 \pm 0.06 \mu \mathrm{g} / \mathrm{ml}\right.$ ) and $\beta$-carotene bleaching assay $(\% \mathrm{I}$ : $78.51 \pm 0.42 \%$ ) showed significant in vitro antioxidant property.

Conclusion: L. glutinosa stem bark essential oil showed potential antibacterial activity against the Vibrio cholera. The results of this investigation supported the ethnomedical claim of essential oil as a demulcent, antidiarrheal and antioxidant drug.

Keywords: Litsea glutinosa, Stem bark essential oil composition, GC-MS, Antibacterial and Antioxidant activity

(C) 2016 The Authors. Published by Innovare Academic Sciences Pvt Ltd. This is an open access article under the CC BY license (http://creativecommons.org/licenses/by/4. 0/) DOI: http://dx.doi.org/10.22159/ijpps.2016v8i12.13577

\section{INTRODUCTION}

Litsea glutinosa is an endemic and threatened aromatic medicinal tree which belongs to the Lauraceae family and found to be very sparsely distributed in the Western Ghats of Karnataka State, India. Leaves and stem bark essential oil possess allspice aroma. Traditional medicinal practitioners residing in the vicinity of Bhadra Wild Life Sanctuary are using L. glutinosa stem bark oil as the demulcent and mild astringent for diarrhea and dysentery. It is also reported for relieving pain, arousing sexual power, aches, sore eyes, skin infections, gouty joints, wounds and also for producing a soothing effect on the body [1-3]. The leaf extract has been evaluated for cardiovascular and antiinflammatory activities [4]. The berries oil is used in the treatment of rheumatism and shampoo preparation [5].

Essential oils from aromatic and medicinal plants have been known from ancient times to possess biological activity [6]. They have been screened for their potential uses as alternative remedies for the treatment of many infectious diseases and the preservation of foods from the toxic effects of oxidants, notably antibacterial [7], antifungal [8] and antioxidant properties [9].

Recently, aromatic medicinal plants and their essential oils have provoked interest in the isolation of novel biologically active compounds for the elimination of pathogenic microorganisms. Many pathogenic microbes evolved as multi-drug resistant (MDR) strains which acquire resistance against the known antibiotics [10]. Further, bacterial infections pose a greater threat to health, most notably in immune compromised subjects. Hence, it is essential to investigate the cheap and effective antimicrobial agents to combat microbial infections. The chemical composition and bioactivities of stem bark essential oil of $L$. glutinosa are unexplored. Therefore, an attempt was made to analyze the chemical composition of the stem bark essential oil and to evaluate the antibacterial and antioxidant activities to authenticate the traditional claim of the essential oil as the antidiarrheal drug.

\section{MATERIALS AND METHODS}

\section{Chemicals and reagents}

2,2-Diphenyl-2-picrylhydrazyl (DPPH), 2,2-azino-bis(3-ethylbenzo thiazoline)-6-sulfonic acid (ABTS) was obtained from Sigma Chemical Co. (St. Louis, MO, USA), butylated hydroxyl anisole (BHA), butylated hydroxytoluene (BHT), trichloroacetic acid (TCA), folin-ciocalteu reagent, dimethyl sulfoxide (DMSO) were purchased from Merck limited (Mumbai, India), resazurin, hi sensitivity broth, $\beta$-carotene, potassium persulfate, linoleic acid, ascorbic acid, nutrient agar (NA) media, sodium sulfate, gentamicin and ampicillin dish were procured from Himedia Pvt. Labs. (Mumbai, India). All other chemicals and solvents used were of analytical grade. Purified water from MiliQ water purification system (Millipore, Bedford, MA, USA) was used in all the experiments.

\section{Plant material}

The stem bark of L. glutinosa was collected from Bhadra Wild Life Sanctuary of the central Western Ghats, Karnataka, India during December 2013. The plant specimen was identified and authenticated by Tariq Husain, Head, Scientist, Biodiversity and Angiosperm Taxonomy, National Botanical Research Institute, Lucknow, India and the voucher specimen (No. 97294) was deposited.

\section{Extraction of essential oil}

A $250 \mathrm{~g}$ of air dried chopped and ground bark powder of L. glutinosa was subjected to hydrodistillation using a modified Clevenger-type apparatus [11]. Subsequently, obtained aromatic oil was dried over anhydrous sodium sulfate and preserved in sealed amber colored vial at $4{ }^{\circ} \mathrm{C}$ prior to analysis.

\section{GC-MS analysis of the essential oil}

The chemical composition of the stem bark essential oil was analyzed using Shimadzu GCMS-QP2010S instrument with GC-MS 
solutions software and compounds were separated using Rtx-5, capillary column $(0.25 \mathrm{~mm}, 0.25 \mu \mathrm{m})$. Split ratio $1: 25$ injector temperature was $300{ }^{\circ} \mathrm{C}$; the column temperature was maintained at $60{ }^{\circ} \mathrm{C}$, followed by $10 \mathrm{~min}$ at $300{ }^{\circ} \mathrm{C}$. About $1 \mu \mathrm{l}$ sample was injected into the column by the split mode. GC-MS was performed by an electron ionization system, with ionization of $70 \mathrm{eV}$. The helium was used as carrier gas at a flow rate of $1 \mathrm{ml} / \mathrm{min}$; Mass scanning range was $40-500 \mathrm{~m} / \mathrm{z}$ [12]. Interpretation of GC-MS chromatogram was conducted using the two databases of NIST05 and WILY7 mass spectral libraries which provide the best information about the identification of components. The name, molecular weight and structure of the components of stem bark essential oil were ascertained.

\section{Antibacterial activity}

\section{Microbial strains}

The antibacterial activity of the stem bark essential oil was individually tested against a set of seven bacterial human pathogenic clinical isolates obtained from Shivamogga Institute of Medical Sciences, Shivamogga, Karnataka. namely: E. coli, Pseudomonas aeruginosa, Salmonella typhi, Vibrio cholera, Klebsiella pneumonia, Staphylococcus aureus, Streptomyces pneumonia and Bacillus subtilis. Bacterial isolates were cultured overnight at $37^{\circ} \mathrm{C}$ in nutrient agar (NA) media.

\section{Disk diffusion assay}

Determination of antibacterial activity of stem bark essential oil was evaluated by agar disk diffusion method [13]. $100 \mu \mathrm{l}$ of the suspension containing 108 colony forming units $\mathrm{CFU} / \mathrm{ml}$ of bacteria were spread on NA media, respectively. Sterile filter discs (6 $\mathrm{mm}$ in diameter) were placed onto the surface of the agar plates and $5 \mu \mathrm{l}$ of essential oil was pipetted onto the discs. Plates were kept at $4{ }^{\circ} \mathrm{C}$ for $1 \mathrm{~h}$ and then incubated for $24 \mathrm{~h}$ at $37^{\circ} \mathrm{C}$. Gentamycin $(10 \mu \mathrm{g} / \mathrm{dish})$ and ampicillin $(10 \mu \mathrm{g} / \mathrm{dish})$ were used as a positive control for bacteria. While the discs without samples were used as a negative control. Antibacterial activity was assessed by measuring the diameter of the growth inhibition zone in millimeters (including disc diameter of $6 \mathrm{~mm}$ ) for the test organisms compared to the control [14].

\section{Resazurin microtitre-plate assay}

The minimum inhibitory concentration (MIC) of the stem bark essential oil was evaluated by modified resazurin microtitre plate assay [15]. $50 \mu \mathrm{l}$ of test sample containing $250 \mu \mathrm{g}$ of essential oil $[5 \mathrm{mg} / \mathrm{ml}(\mathrm{w} / \mathrm{v})]$ solutions in $10 \%$ dimethyl sulfoxide (DMSO, $\mathrm{v} / \mathrm{v}$ ) and $50 \mu \mathrm{g}$ of standard antibiotic $[1 \mathrm{mg} / \mathrm{ml}$ $(\mathrm{w} / \mathrm{v})]$ solutions in $10 \%$ DMSO was transferred into the first row of eight of 96 well plates. To all wells, $50 \mu \mathrm{l}$ of nutrient broth was added. Two-fold serial dilutions were performed using a multichannel pipette such that each well had $50 \mu \mathrm{l}$ of the test material in serially descending concentrations. $30 \mu \mathrm{l}$ of 3.3 times stronger hi sensitivity broth $(3.3 \mathrm{x})$ and $10 \mu \mathrm{l}$ of resazurin indicator solution (prepared by dissolving $27 \mathrm{mg}$ resazurin in 4 $\mathrm{ml}$ of sterile distilled water) were added to each well. Finally, 10 $\mu \mathrm{l}$ of bacterial suspension was added to the appropriate wells to achieve a concentration of approx $5 \times 106 \mathrm{CFU} / \mathrm{ml}$.

Each plate was wrapped loosely with cling film to ensure that bacteria did not become dehydrated. Each plate had a set of controls: column with all solutions with the exception of the test compound (as growth control), column with all solutions with the exception of the bacterial solution adding $10 \mu \mathrm{l}$ of nutrient broth instead (as sterility control) and a column with 10\% DMSO $(\mathrm{v} / \mathrm{v})$ solution as a negative control. Gentamycin and ampicillin were used as positive controls. The plates were prepared in duplicate, incubated at $37{ }^{\circ} \mathrm{C}$ for $24 \mathrm{~h}$ and color change was assessed visually. The growth was indicated by color changes from purple to pink or colorless. The lowest concentration at which color change appeared was taken as the MIC value.

\section{Determination of antioxidant activity DPPH radical scavenging activity}

The antioxidant activity of $L$. glutinosa stem bark essential oil was assayed through TLC method [16]. $5 \mu \mathrm{l}$ of the essential oil (1:10 dilution in methanol) was applied on TLC plate and developed in ethyl acetate and methanol [1:1 (v/v)]. The plate was sprayed with $0.2 \%$ DPPH solution in methanol and left at room temperature for $30 \mathrm{~min}$. Yellow spot formed due to bleaching of purple color of DPPH reagent indicates positive antioxidant activity of essential oil. Different concentrations of the essential oil ( 2 to $10 \mu \mathrm{g} / \mathrm{ml}$ ) and the standard BHA $2-10 \mu \mathrm{g} / \mathrm{ml}$ were added to $0.004 \%$ methanolic solution of DPPH. After 30 min of incubation at room temperature $\left(25 \pm 2{ }^{\circ} \mathrm{C}\right)$, the absorbance was read at $517 \mathrm{~nm}$ using a spectrophotometer. Radical scavenging activity was calculated by the evaluation of $\%$ of inhibition and $\mathrm{IC}_{50}$ value [17]

\section{ABTS radical scavenging activity}

The radical scavenging capacity of the ABTS radical cation was determined as described by Re et al. [18]. The ABTS radical was generated by mixing equal volume $(\mathrm{v} / \mathrm{v})$ of $7 \mathrm{mmol}$ ABTS and 2.6 mmol potassium persulfate and kept for incubation overnight at room temperature under dark condition. $150 \mu \mathrm{l}$ of essential oil and standard BHT at different concentrations were allowed to react with $2.85 \mu \mathrm{l}$ of ABTS mixture and were incubated at room temperature for $2 \mathrm{~h}$ in dark condition. The scavenging activity was determined by measuring the absorbance at $734 \mathrm{~nm}$ and the \% of inhibition and $\mathrm{IC}_{50}$ value was calculated [19].

\section{$\boldsymbol{\beta}$-carotene/linoleic acid assay}

The antioxidant activity of stem bark essential oil was determined by measuring the efficacy of oil to inhibit the conjugated diene hydroperoxide formation arising from linoleic acid and $\beta$-carotene coupled oxidation in an emulsified aqueous system [20]. A stock solution of $\beta$-carotene and linoleic acid was prepared with $0.5 \mathrm{mg}$ of $\beta$ carotene in $1 \mathrm{ml}$ of chloroform, $25 \mu \mathrm{l}$ of linoleic acid and $200 \mu \mathrm{l}$ Tween 80 . The chloroform was completely evaporated under vacuum in a Buchi-R3 rotary evaporator (Flawil, Switzerland) at $40{ }^{\circ} \mathrm{C} .100 \mathrm{ml}$ of oxygenated distilled water was then added to the residue and the resulting mixture was vigorously stirred to form a $\beta$-carotene-linoleic acid emulsion. The samples $(2 \mathrm{~g} / \mathrm{l})$ were dissolved in DMSO and $350 \mu \mathrm{l}$ of each sample solution was added to $2.5 \mathrm{ml}$ of the above mixture in test tubes. The test tubes were incubated in a water bath at $50{ }^{\circ} \mathrm{C}$ for 2 $\mathrm{h}$, together with positive control and the same volume of DMSO used as blank. As the test samples added with $\beta$-carotene-linoleic acid emulsion, the zero time absorbance (Ao) was measured at $470 \mathrm{~nm}$. Second absorbance (At) was measured after $2 \mathrm{~h}$ of incubation. BHA and ascorbic acid were used as positive controls.

\section{Statistical analysis}

The statistical analysis was performed by one-way ANOVA in Graphpad prism Version 5.01 Software. The results were expressed as mean \pm SEM.

\section{RESULTS}

\section{Essential oil composition of stem bark}

The amount of essential oil obtained from the stem bark of $L$. glutinosa was $2.3 \mathrm{ml} / 100 \mathrm{~g}$ dry weight, with characteristic aroma of allspice (Pimenta dioica). The GC-MS data revealed that L. glutinosa stem bark essential oil composed of 38 peaks as shown in the fig. 1.

\section{Antibacterial activity of stem bark essential oil}

The essential oil isolated from L. glutinosa stem bark exhibited varying antibacterial activity against the tested pathogenic microbial strains and are shown in table 2. The results of the disc diffusion assay followed by modified resazurin assay (fig $2 \mathrm{~A}, \mathrm{~B}, \mathrm{C}$ ) indicated that the stem bark essential oil exhibited highest inhibitory activity against gram-negative bacteria Vibrio cholera with a significant inhibition zone of $15.00 \pm 0.57 \mathrm{~mm}$ and MIC value of $0.15 \pm 0.15 \times 10^{-2} \mathrm{mg} / \mathrm{ml}$ 

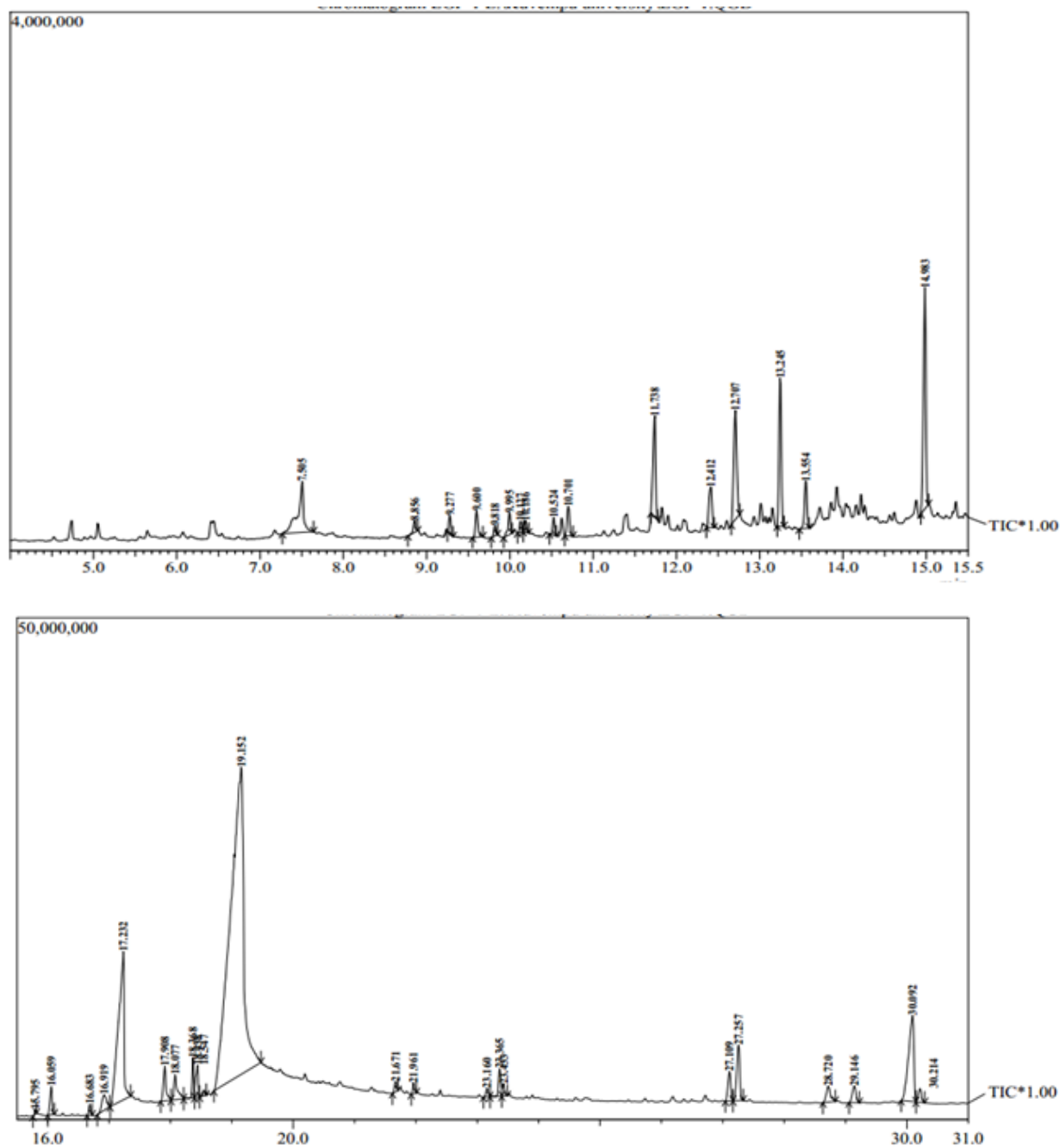

Fig. 1: It shows GC-MS chromatograms of L. glutinosa stem bark essential oil

Table 1: Showing chemical composition of L. glutinosa stem bark essential oil

\begin{tabular}{|c|c|c|c|c|}
\hline S. No & R. Time & RI & Yield \% & Compound \\
\hline 1 & 7.505 & 998 & 0.25 & Octanoic acid (CAS) Caprylic acid \\
\hline 2 & 8.856 & 1078 & 0.02 & Nonanoic acid \\
\hline 3 & 9.277 & 1102 & 0.03 & 2, 4-Dodecadienal, $(E, E)$ \\
\hline 4 & 9.600 & 1123 & 0.06 & 2, 4 Decadienal \\
\hline 5 & 9.818 & 1136 & 0.02 & 1-Butene, 2, 3-dimethyl \\
\hline 6 & 9.995 & 1147 & 0.05 & 5-pentyl-2(5H)-furanone \\
\hline 7 & 10.127 & 1155 & 0.02 & . alpha.-Cubebene \\
\hline 8 & 10.186 & 1159 & 0.02 & Decanoic acid (CAS) Capric acid \\
\hline 9 & 10.524 & 1180 & 0.03 & Copaene \\
\hline 10 & 10.701 & 1191 & 0.06 & beta.-elemene \\
\hline 11 & 11.738 & 1260 & 0.22 & 9-Oxononanoic acid \\
\hline 12 & 12.412 & 1304 & 0.11 & $1 S$, cis-calamenene \\
\hline 13 & 12.707 & 1325 & 0.28 & Dodecanoic acid (CAS) Lauric acid \\
\hline 14 & 13.245 & 1363 & 0.28 & (-)-Caryophyllene oxide \\
\hline 15 & 13.554 & 1385 & 0.10 & Humulene oxide \\
\hline 16 & 14.983 & 1486 & 0.45 & Tetradecanoic acid (CAS) Myristic acid \\
\hline 17 & 15.795 & 1543 & 0.11 & Neophytadiene \\
\hline 18 & 16.059 & 1562 & 0.90 & Pentadecanoic acid (CAS) Pentadecylic acid \\
\hline 19 & 16.683 & 1606 & 0.28 & Hexadecanoic acid, methyl ester \\
\hline 20 & 16.919 & 1623 & 1.09 & Octadec-9-enoic acid \\
\hline 21 & 17.232 & 1645 & 12.68 & Hexadecanoic acid (CAS) Palmitic acid \\
\hline 22 & 17.908 & 1693 & 1.41 & Oleic Acid \\
\hline 23 & 18.077 & 1705 & 1.30 & Heptadecanoic acid (CAS) Margaric acid \\
\hline 24 & 18.368 & 1725 & 0.97 & 9, 12-Octadecadienoic acid $(Z, Z)-$, methyl ester \\
\hline 25 & 18.438 & 1731 & 1.13 & $9,12,15$-Octadecatrienoic acid, methyl ester \\
\hline 26 & 18.547 & 1738 & 0.16 & 2-Hexadecen-1-ol, 3, 7,11, 15-tetramethyl- \\
\hline
\end{tabular}




\begin{tabular}{lllll}
\hline 27 & 19.152 & 1781 & 62.57 & 9,12 -Octadecadienoic acid (Z,Z)- \\
28 & 21.671 & 1959 & 0.36 & 9-Octadecenoic acid, 1, 2, 3-propanetriyl ester \\
29 & 21.961 & 1979 & 0.29 & Hexadecanoic acid, 2-hydroxy-1-(hydroxymethyl) ethyl ester \\
30 & 23.160 & 2064 & 0.31 & Oleoyl chloride \\
31 & 23.365 & $2079 !$ & 0.96 & Propyleneglycol monoleate \\
32 & 23.433 & 2083 & 0.38 & Ethyl Linoleolate \\
33 & 27.109 & 2343 & 1.25 & Unknown compound \\
34 & 27.257 & 2354 & 2.51 & Vitamin E \\
35 & 28.720 & 2457 & 0.97 & Ergost-5-en-3-ol, (3. beta.)- \\
36 & 29.146 & 2488 & 0.90 & Stigmasta-5, 22-dien-3-ol, (3. beta., 22E)-(CAS) Stigmasterol \\
37 & 30.092 & 2554 & 6.87 & Stigmast-5-en-3-ol, (3. beta., 24S)-(CAS) Clionasterol \\
38 & 30.214 & 2563 & 0.64 & Cholestanol \\
& Total & & 100.00 & \\
\hline
\end{tabular}

*RI: Relative Retention indices to C8-C29 n-alkanes on Rtx-5 capillary column, *Compounds listed in order of elution from Rtx-5 capillary column

Table 2: Antibacterial activity of the L. glutinosa essential oil

\begin{tabular}{|c|c|c|c|c|c|c|}
\hline \multirow[t]{3}{*}{ Microorganisms } & \multicolumn{6}{|c|}{ Inhibition zone diameter $(\mathrm{mm})$ and MIC $\left(\mathrm{mgml}^{-1}\right)$} \\
\hline & \multicolumn{2}{|c|}{ Essential oil (5 $\mu \mathrm{l} /$ disc $)$} & \multicolumn{2}{|c|}{ Gentamycin $(10 \mu \mathrm{g} /$ disc $)$} & \multicolumn{2}{|c|}{ Ampicillin $(10 \mu \mathrm{g} / \mathrm{disc})$} \\
\hline & IZ & MIC & IZ & MIC & IZ & MIC \\
\hline \multicolumn{7}{|l|}{ Gram-negative } \\
\hline E. coli & $11.00 \pm 0.57$ & $6.25 \pm 0.10 \times 10^{-2}$ & $29.67 \pm 0.33$ & $1.56 \pm 0.10 \times 10^{-3}$ & $16.33 \pm 0.88$ & $8.33 \pm 0.20 \times 10^{-3}$ \\
\hline P. aeruginosa & $14.33 \pm 0.66$ & $6.25 \pm 0.10 \times 10^{-2}$ & $39.67 \pm 0.33$ & $0.65 \pm 0.10 \times 10^{-3}$ & $49.67 \pm 0.33$ & $2.08 \pm 0.05 \times 10^{-3}$ \\
\hline S. typhi & $11.33 \pm 0.33$ & $1.30 \pm 0.20 \times 10^{-2}$ & $29.00 \pm 0.57$ & $2.08 \pm 1.30 \times 10^{-3}$ & $41.00 \pm 0.57$ & $4.16 \pm 0.01 \times 10^{-3}$ \\
\hline V. cholera & $15.00 \pm 0.57$ & $0.15 \pm 0.15 \times 10^{-2}$ & $34.00 \pm 1.00$ & $7.81 \pm 0.10 \times 10^{-3}$ & $44.33 \pm 0.66$ & $4.16 \pm 0.10 \times 10^{-3}$ \\
\hline K. pneumonia & $10.33 \pm 0.33$ & $3.12 \pm 0.41 \times 10^{-2}$ & $24.33 \pm 0.66$ & $4.16 \pm 0.10 \times 10^{-3}$ & ------ & $25.0 \pm 0.10 \times 10^{-3}$ \\
\hline \multicolumn{7}{|l|}{ Gram-positive } \\
\hline S. aureus & $09.66 \pm 0.33$ & $12.5 \pm 0.01 \times 10^{-2}$ & $24.67 \pm 0.33$ & $4.16 \pm 0.10 \times 10^{-3}$ & $12.67 \pm 0.66$ & $5.20 \pm 0.10 \times 10^{-3}$ \\
\hline S. pneumonia & $10.00 \pm 0.57$ & $3.12 \pm 0.01 \times 10^{-2}$ & $23.33 \pm 0.88$ & $4.16 \pm 0.10 \times 10^{-3}$ & $08.33 \pm 0.33$ & $16.6 \pm 0.10 \times 10^{-3}$ \\
\hline B. subtilis & $11.33 \pm 0.33$ & $3.12 \pm 0.01 \times 10^{-2}$ & $26.67 \pm 0.66$ & $4.16 \pm 0.10 \times 10^{-3}$ & $10.33 \pm 0.33$ & $5.20 \pm 0.10 \times 10^{-3}$ \\
\hline
\end{tabular}

Values are mean \pm standard error $(\mathrm{n}=3)$ of three different samples, analyzed individually in triplicate, IZ, the diameter of inhibition zone (mm) including disc diameter of $6 \mathrm{~mm}$, MIC, minimum inhibitory concentration $(\mathrm{mg} / \mathrm{ml})$.

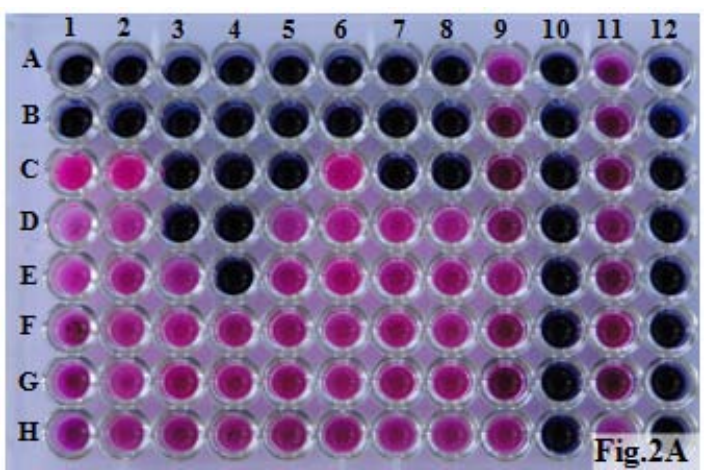

Fig. 2A: Modified resazurin assay results of stem bark essential oil in decreased concentrations of $50 \mu \mathrm{l}$ to $0.39 \mu \mathrm{l}$

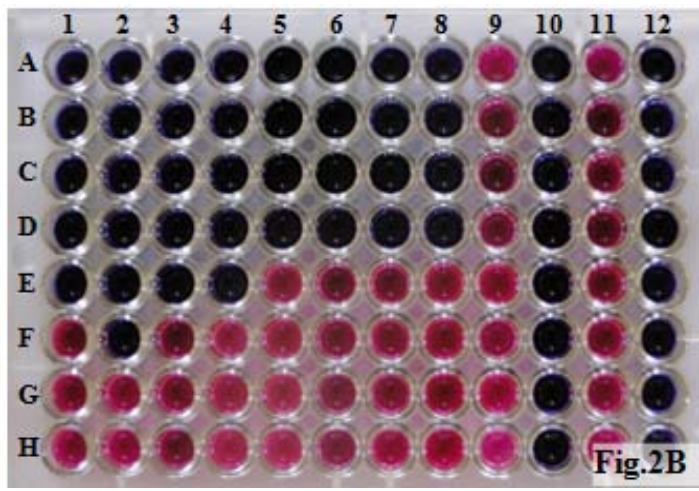

Fig. 2B: Modified resazurin assay results of gentamycin in decreased concentrations of $50 \mu \mathrm{l}$ to $39 \mu \mathrm{g} / \mathrm{ml}$

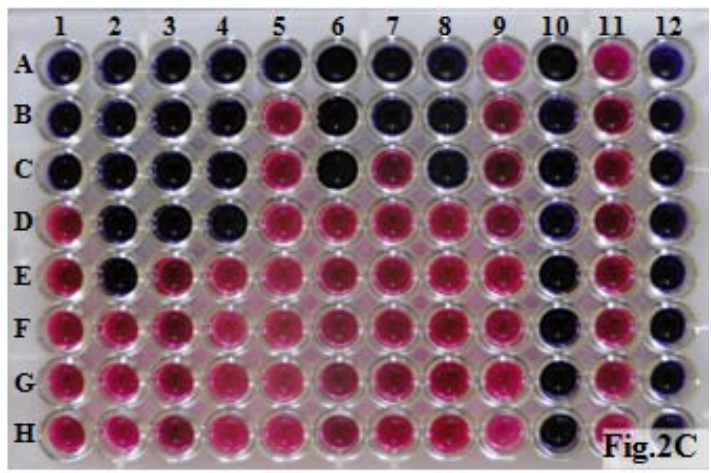

Fig. 2C: Modified resazurin assay results of ampicillin in decreased concentrations of $50 \mu \mathrm{l}$ to $39 \mu \mathrm{g} / \mathrm{ml}$

\section{Antioxidant activity}

Plants with radical scavenging property and antioxidant capacity are useful for medicinal applications and as a food additive. So, in the present study, the antioxidant capacity of L. glutinosa was evaluated using DPPH, ABTS free radical scavenging and $\beta$-carotene linoleic acid bleaching assay by comparing with the known antioxidant such as ascorbic acid, BHA and BHT respectively.

Discoloration of the purple color of the DPPH radical on TLC plates was assessed as a positive sign of antioxidant activity of oil. The stem bark essential oil showed DPPH and ABTS free radical scavenging activity in a dose-dependent manner and its $\mathrm{IC}_{50}$ values of DPPH and ABTS assay is $4.540 \pm 0.06 \mu \mathrm{g} / \mathrm{ml}$ and $256.02 \pm 0.06$ $\mu \mathrm{g} / \mathrm{ml}$ respectively. In $\beta$-carotene bleaching assay, the inhibiting activity of oil was $78.51 \pm 0.42 \%$ which was higher than that of synthetic antioxidant ascorbic acid $(63.33 \pm 0.71 \%)$ and less than BHA $(93.42 \pm 0.40 \%)$ as shown in table 3 . 
Table 3: DPPH, ABTS radical scavenging and $\beta$-carotene bleaching assay

\begin{tabular}{|c|c|c|c|c|c|c|c|}
\hline \multirow[t]{2}{*}{ S. No } & \multirow[t]{2}{*}{ Activity } & \multirow[t]{2}{*}{ Concentration in $\mu \mathrm{g} / \mathrm{ml}$} & \multirow[t]{2}{*}{$\%$ of Inhibition } & \multirow[t]{2}{*}{ IC $50 \mu \mathrm{g} / \mathrm{ml}$} & \multicolumn{3}{|c|}{ Standard $\mathrm{IC}_{50}$ in $\mu \mathrm{g} / \mathrm{ml}$} \\
\hline & & & & & BHA & BHT & Vit C \\
\hline \multirow[t]{5}{*}{1} & DPPH & 2 & $5.70 \pm 0.52$ & $4.540 \pm 0.06$ & $19.13 \pm 0.05$ & 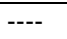 & $\begin{array}{ll}--- \\
-1\end{array}$ \\
\hline & & 4 & $10.51 \pm 1.45$ & & & & \\
\hline & & 6 & $15.23 \pm 1.23$ & & & & \\
\hline & & 8 & $20.01 \pm 0.71$ & & & & \\
\hline & & 10 & $26.92 \pm 1.47$ & & & & \\
\hline \multirow[t]{6}{*}{2} & ABTS & 100 & $23.80 \pm 0.55$ & $256.02 \pm 0.06$ & ---- & 4.448 & 05---- \\
\hline & & 200 & $46.66 \pm 1.65$ & & & & \\
\hline & & 300 & $70.15 \pm 2.48$ & & & & \\
\hline & & 400 & $81.90 \pm 1.10$ & & & & \\
\hline & & 500 & $89.52 \pm 1.10$ & & & & \\
\hline & & 600 & $98.09 \pm 0.55$ & & & & \\
\hline 3 & $\beta$-carotene & 700 & $78.51 \pm 0.42$ & ---- & $93.42 \pm 0.42$ & ---- & $63.33 \pm 0.71$ \\
\hline
\end{tabular}

The results shown are averages of three independent experiments $(n=3)$, values are mean \pm SEM.

\section{DISCUSSION}

Litsea glutinosa is an aromatic tree mainly growing in tropical and subtropical Asia [21] and many investigators explored the antimicrobial activity of the essential oil isolated from this species [22]. In the present investigation, major aromatic constituents were isolated and their biological activity was screened for antioxidant and antibacterial activity against the selected human pathogenic bacteria.

The GC-MS results of L. glutinosa stem bark isolate revealed the presence of 38 aromatic compounds. Among the major constituents identified, 9,12-octadecadienoic acid (Z,Z)-Linoleic acid (R/T 19.152) possesses anti-inflammatory, nematicide, insectifuge, hypocholesterolemic, cancer preventive, hepatoprotective, antihistaminic, anti-acne, antiarthritic, antieczemic, antiandrogenic, 5alpha reductase inhibitor and anti-coronary activity [23]. The hexadecanoic acid (R/T 17.235) can be a hypocholesterolemic, nematicide, pesticide and lubricant activities and it was also reported as a more effective free radical scavenger than $\beta$-carotene $[23,24]$. (3ß)-Stigmast-5-en-3-ol has shown an insulin-like effect, it stimulates glucose transport apart from its existing cholesterollowering efficacy. Therefore, it can play a beneficial role as an antidiabetic agent [25]; it can also prevent diabetic neuropathy, a painful condition resulting from exposure of nerves to high glucose levels [26]. Vitamin E is known to possess anti-ageing, analgesic, antidiabetic, anti-inflammatory, antioxidant, anti-dermatitic, antileukemic, anticancer, hepatoprotective, hypocholesterolemic, antiulcerogenic, vasodilator, antispasmodic, anti-bronchitic, and anticoronary activity [23]. Fruits, plants and vegetables are the main sources of antioxidant vitamins (vitamin E, vitamin $C$, the precursor of vitamin $A$ i.e., $\beta$-carotene), which act as free radical scavengers, making these foods essential to human health.

Presently, much attention has been given to plant-derived essential oils, as they possess various pharmaceutical properties such as antibacterial, antioxidant, antiviral, anti-insecticidal, anti-mycotic, and anti-toxinogenic activities [27-30]. From the ancient times, many plant oils have been used as topical antiseptics and also it is used to improve food safety and quality [16]. The antimicrobial activities of fatty acids have been well known from many years [31, 32] and also these were bactericidal compounds against the pathogenic microorganisms including antibiotic-resistant Staphylcoccus aureus [33, 34]. Linoleic, palmitic, linolenic, lauric, oleic, stearic myristic acids etc. Isolated from the stem bark of $L$. glutinosa were reported as the potential antibacterial drugs [35, 36]. GC-MS results of this study also confirmed the presence of a higher percentage of linoleic $(9,12$-Octadecadienoic acid) and palmitic (Hexadecanoic acid) fatty acids in the stem bark.

The traditional claim indicated that the stem bark oil of L. glutinosa has been used to control diarrhea and dysentery which is caused by the gram-negative bacterial strain Vibrio cholera. In the present study also stem bark essential oil of L. glutinosa exhibited lowest MIC values than the tested gram-positive strains. Generally, gramnegative bacteria showed less sensitivity to plant extract when compared to gram positive bacteria because of extra lipopolysaccharide and protein cell wall $[37,38]$. Whereas, the zone of inhibition efficiency of stem bark essential oil was more $(15.00 \pm 0.57 \mathrm{~mm})$ against the Vibrio cholera culture. The results obtained in the present study are in agreement with the traditional medicinal claim as the potential antidiarrheal drug. Vardar Unlu et al., [39] Suggested that the simple relation involving cell structure and microbial sensitivity to essential oils is not yet well established and possible antagonistic or synergistic effects among the various active constituents of the oils should be taken into consideration. The previous investigator Parikh et al., [40] also reported that decoction of stem bark was prescribed as the remedy for diarrhea and dysentery. So our results were in accordance with the earlier reports on the antidiarrheal property of the stem bark essential oil.

The generation of reactive oxygen species (ROS) and free radicals beyond the antioxidant capacity of a biological system gives rise to oxidative stress during aerobic cellular metabolism and eventually associated with the pathogenesis of a variety of human diseases such as atherosclerosis, diabetes mellitus, hypertension, inflammation, cancer, neurodegenerative disorders, aging, ulcerative colitis, and cirrhosis [41-44]. Nowadays, there is growing interest in evaluating the availability of natural plant extracts as an alternative of synthetic antioxidants, such as BHT, BHA and ascorbic acid, which are commonly used in processed foods, it has been showed that these compounds have side effects in living organisms [45]. Hence, search for newer natural antioxidants, especially of plant origin, has ever since increased.

Reports also indicated that essential oil showed preservative action and they prevent lipid deterioration by the microorganism spoilage $[46,47]$. Fatty acids can also attribute to antioxidant activity. In the case of the antioxidant assay, the DPPH, ABTS and $\beta$-carotenelinoleic acid test gave a significant result. The GC-MS analysis of the stem bark essential oil revealed the presence of palmitic acid in a higher percentage (12.68\%). Palmitic acid was reported to be a more effective free radical scavenger than $\beta$-carotene [48]. Stigmast5-en-3-ol and vitamin $c$ which are present in this oil may also contribute to the antioxidant activity which clearly indicates that essential oil possesses significant antioxidant activity, which is widely used as food preservatives in food technology $[49,50]$. The higher content of fatty acids-linoleic acid, palmitic acid and Vitamin $\mathrm{C}$ in the stem bark essential oil could be responsible for the increased antibacterial and antioxidant activity.

\section{CONCLUSION}

In conclusion, the GC-MS analysis of L. glutinosa stem bark essential oil showed a higher concentration of 9, 12-octadecadienoic acid $(62.57 \%)$ which exhibited promising antidiarrheal activity against the human pathogenic bacterial strain. The DPPH radical scavenging, ABTS and $\beta$-carotene bleaching assay of essential oils also showed significant in vitro antioxidant property. The result of the present study further supports the ethnomedical claim of $L$. glutinosa stem bark oil as the demulcent and mild astringent for diarrhea and dysentery. The therapeutic action of the 9,12-octadecadienoic acid 
will be correlated with the effect of the reference standard dug in the future investigation.

\section{ACKNOWLEDGEMENT}

The authors wish to thank the UGC New Delhi [F No. 4-10/2010 (BSR)] for providing financial assistance and the Administrative authority Kuvempu University for providing facility for carrying out the investigation. We thanks to the faculty of Shivamogga Institute of Medical Sciences, Shivamogga, Karnataka, India for providing human pathogenic clinical isolates.

\section{CONFLICT OF INTERESTS}

We declare that we have no conflict of interest.

\section{REFERENCES}

1. Kirtikar K, Basu B. Indian medicinal plants. Allahabad; 1981. p. 2156-61.

2. Anonymous. The wealth of India, Material: L-M, CSIR, India; 1998. p. 229-32.

3. Rajendra K, Shakthi upadyay. Free radical scavenging activity screening of medicinal plants from Tripura, North east India. Indian J Nat Prod Resour 2009;8:117-22.

4. Kar A, Menon MK, Chauhan CS. Effect of essential oil of Litsea glutinosa (Lour.) C. B. Robinson on cardiovascular system and isolated tissues. Indian J Exp Biol 1970;2:61-2.

5. Chowdhury JU, Bhuiyan NI, Nandi NC. Aromatic plants of Bangladesh : Essential oils of leaves and fruits Of Litsea glutinosa (Lour.) C. B. Robinson. Bangladesh J Bot 2008;37:81-3.

6. Deans SG, Waterman PG. In: Volatile Oil Crops: Their Biology, Biochemistry and Production. ed. Hay RKM, Waterman PG. Longman, London; 1993. p. 113.

7. Bachir RG, Benali M. Antibacterial activity of the essential oils from the leaves of Eucalyptus globulus against Escherichia coli and Staphylococcus aureus. Asian Pac J Trop Biomed 2012;2:739-42.

8. Mahilrajan S, Nandakumar J, Kailayalingam R, Manoharan NA, SriVijeindran S. Screening the antifungal activity of essential oils against decay fungi from palmyrah leaf handicrafts. Biol Res 2014;47:35.

9. Preedy, Victor R. Essential oils in food preservation, flavor and safety. Elsevier; 2016.

10. Davies J, Davies D. Origins and evolution of antibiotic resistance. Microbiol Mol Biol Rev 2010;74:417-33.

11. European Council. European pharmacopoeia. 8th ed. Strasbourg; 2014.

12. Sahoo S, Singh S, Nayak S. Chemical composition, antioxidant and antimicrobial activity of essential oil and extract of Alpinia malaccensis roscoe (zingiberaceae). Int J Pharm Pharm Sci 2014;6:183-8.

13. Performance standards for antimicrobial disk susceptibility tests. Wayne PA: National Committee for Clinical Laboratory Standards; 1997.

14. Moorthy K, Aparna aravind, Punitha T, Vinodhini R, Suresh M. In vitro screening of antimicrobial activity of Wrightia tinctoria (Roxb.) R. Br. Asian J Pharm Clin Res 2012;5:54-8.

15. Sarker SD, Nahar L, Kumarasamy Y. Microtitre plate-based antibacterial assay incorporating resazurin as an indicator of cell growth, and its application in the in vitro antibacterial screening of phytochemicals. Methods 2007;42:321-4.

16. Tepe B, Daferera D, Sokmen A, Sokmen M, Polissiou M. Antimicrobial and antioxidant activities of the essential oil and various extracts of Salvia tomentosa Miller (Lamiaceae). Food Chem 2005;90:333-40.

17. Archana D, Dixitha M, Santhy KS. Antioxidant and anticlastogenic potential of piper Longum L. Int J Appl Pharm 2015; 7:11-4.

18. Re R, Pellegrini N, Proteggente A, Pannala A, Yang M. Antioxidant activity applying an improved ABTS radical cation decolorization assay. Free Radical Biol Med 1999;26:1231-7.

19. Raaman N. Antioxidant activites and phytochemical analysis of methanol extract of leaves of Hygrophila auriculata (Schumach) heine. Int J Curr Pharm Res 2015;7:100-5.

20. Ebrahimabadi AH, Ebrahimabadi EH, Djafari-Bidgoli Z, Kashi FJ, Mazoochi A. Composition and antioxidant and antimicrobial activity of the essential oil and extracts of Stachys inflata Benth from Iran. Food Chem 2010;119:452-8.

21. Wang YS, Liao Z, Li Y, Huang R, Zhang HB. A new megastigmane diglycoside from Litsea glutinosa (Lour.) C. B. Rob. J Braz Chem Soc 2011;22:2234-8.

22. Saleh MA, Clark S, Woodard B, Deolu-Sobogun SA. Antioxidant and free radical scavenging activities of essential oils. Ethnicity Disease 2010;20:78-82.

23. Kumar P, Kumaravel S, Lalitha C. Screening of antioxidant activity, total phenolics and GC-MS study of Vitex negundo. Afr J Biochem Res 2010;4:191-5.

24. Sermakkani M, Thangapandian V. GC-MS analysis of Cassia italica leaf methanol extract. Asian J Pharm Clin Res 2011;5:90-4

25. Sujatha S, Anand S, Sangeetha KN, Shilpa K, Lakshmi J. Biological evaluation of (3ß)-stigmast-5-en-3-ol as potent antidiabetic agent in regulating glucose transport using in vitro model. Int J Diabetes Mellit 2010;2:101-9.

26. Pitel S, Raccah D, Gerbi A, Pieroni G, Vague P. At low doses, a gamma-linolenic acid-lipoic acid conjugate is more effective than docosahexaenoic acid-enriched phospholipids in preventing neuropathy in diabetic rats. J Nutr 2007;137:368-72.

27. Doughari JH, Ndakidemi PA, Human IS, Benade S. Antioxidant, antimicrobial and antiverotoxic potentials of extracts of Curtisia dentata. J Ethnopharmacol 2012;141:1041-50.

28. Cannas S, Molicotti P, Ruggeri M, Cubeddu M, Sanguinetti M. Antimycotic activity of Myrtus communis L. towards Candida spp. from isolates. J Infect Dev Ctries 2013;7:295-8.

29. Rothan HA, Zulqarnain M, Ammar YA, Tan EC, Rahman NA. Screening of antiviral activities in medicinal plants extracts against dengue virus using dengue NS2B-NS3 protease assay. Trop Biomed 2014;31:286-96.

30. Sukphan P, Sritularak B, Mekboonsonglarp W, Lipipun V, Likhitwitayawuid K. Chemical constituents of Dendrobium venustum and their antimalarial and anti-herpetic properties. Nat Prod Commun 2014;9:825-7.

31. Agoramoorthy G, Chandrasekaran M, Venkatesalu V, Hsu MJ. Antibacterial and antifungal activities of fatty acid methyl esters of the blind-your-eye mangrove from India. Brazilian J Microbiol 2007;38:739-42.

32. Raynor L, Mitchell A, Walker R. Antifungal activities of four fatty acids against plant pathogenic fungi. Mycopathologia 2004;157:87-90.

33. Shin SY, Bajpai VK, Kim HR, Kang SC. Antibacterial activity of eicosapentaenoic acid (EPA) against foodborne and food spoilage microorganisms. LWT-Food Sci Technol 2007;40:1515-9.

34. Sado-Kamdem SL, Vannini L, Guerzoni ME. Effect of alphalinolenic, capric and lauric acid on the fatty acid biosynthesis in Staphylococcus aureus. Int J Food Microbiol 2009;129:288-94.

35. McGaw LJ, Jager AK, van Staden J. Isolation of antibacterial fatty acids from Schotia brachypetala. Fitoterapia 2002;73:431-3.

36. Seidel V, Taylor PW. In vitro activity of extracts and constituents of Pelagonium against rapidly growing mycobacteria. Int J Antimicrob Agents 2004;23:613-9.

37. Adwan K, Abu-Hasan N. Gentamicin resistance in clinical strains of Enterobacteriaceae associated with reduced gentamicin uptake. Folia Microbiol (Praha) 1998;43:438-40.

38. Kaur GJ, Arora DS. Antibacterial and phytochemical screening of Anethum graveolens, Foeniculum vulgare and Trachyspermum ammi. BMC Complement Altern Med 2009;9:30.

39. Vardar-Unlu G, Candan F, Sokmen A, Daferera D, Polissiou M. Antimicrobial and antioxidant activity of the essential oil and methanol extracts of Thymus pectinatus Fisch. et Mey. Var. pectinatus (Lamiaceae). J Agric Food Chem 2003;51:63-7.

40. Parikh PH, Rangrez AY. Extraction and phytochemical evaluation of Litsea glutinosa bark methanolic extract. J Appl Pharm Sci 2012;2:71-8.

41. Gutteridge, JMC, Halliwell B. Antioxidants in nutrition, health, and disease. Oxford University Press, New York; 1994.

42. Maxwell SR. Prospects for the use of antioxidant therapies. Drugs 1995;49:345-61.

43. Sies H. Role of reactive oxygen species in biological processes. Klin Wochenschr 1991;69:965-8.

44. Halliwell B, Gutteridge JMC. Free radicals in biology and medicine. Clarendon Press; 1989. 
45. Ito $\mathrm{N}$, Fukushima $\mathrm{S}$, Hagiwara $\mathrm{A}$, Shibata $\mathrm{M}$, Ogiso $\mathrm{T}$. Carcinogenicity of butylated hydroxyanisole in F344 rats. J Natl Cancer Inst 1983;70:343-52.

46. Sacchetti G, Maietti S, Muzzoli M, Scaglianti M, Manfredini S. Comparative evaluation of 11 essential oils of different origin as functional antioxidants, antiradicals and antimicrobials in foods. Food Chem 2005;91:621-32.

47. Tepe B, Daferera D, Sokmen A, Sokmen M, Polissiou M. Antimicrobial and antioxidant activities of the essential oil and various extracts of Salvia tomentosa miller (Lamiaceae). Food Chem 2005;90:333-40.

48. Kim SY, Jeong SM, Park WP, Nam KC, Ahn DU, et al. Effect of heating conditions of grape seeds on the antioxidant activity of grape seed extracts. Food Chem 2006;97:472-9.
49. Nguefack J, Leth V, Amvam Zollo PH, Mathur SB. Evaluation of five essential oils from aromatic plants of Cameroon for controlling food spoilage and mycotoxin producing fungi. Int J Food Microbiol 2004;94:329-34.

50. Prakash B, Singh P, Kedia A, Dubey NK. Assessment of some essential oils as food preservatives based on antifungal antiaflatoxin, antioxidant activities and in vivo efficacy in food system. Food Res Int 2012;49:201-8.

\section{How to cite this article}

- Arunodaya HS, Krishna V, Shashikumar R, Girish Kumar K Antibacterial and antioxidant activities of stem bark essential oil constituents of Litsea glutinosa C. B. Rob. Int J Pharm Pharm Sci 2016;8(12):258-264 